\title{
エンドトキシンとサイトカイン
}

\author{
松 浦 基 博
}

\author{
自治医科大学・微生物学教室 \\ 厂329-04 栃木県河内郡南河内町薬師寺3311-1 \\ [受理 : 1994年12月19日]
}

\begin{abstract}
エンドトキシンは生体にとって有益な作用から障害的な作用にまで及ぶ，極めて多彩な活性を示す。 その活性発現には, 生体細胞より産生放出される種々の仲介物質の作用が介在していることが明らか になってきている。その仲介物質として，エンドトキシンの主要な標的細胞であるマクロファージ系 細胞から産生放出される，TNF $\alpha$ やIL-1 を始めIL-6，IL-8，IFN $\alpha / \beta$ ，CSF などのサイトカイン類が大 きな位置を占めていると考えられ，その役割の解明が進められている。これらサイトカインは各々が 複数の活性を発現し, 相互に関連し合うため, 活性の発現が複雑多岐にわたり, また, 活性が過剩に 発現された場合には障害的な活性を発現することになると考えられている。サイトカインの産生や作 用を抑制することによって, エンドトキシンショックの治療を目指す研究も進められている。また， エンドトキシン刺激によるサイトカイン産生のための細胞レベルでの刺激伝達機構に関する研究も急 速に発展している。
\end{abstract}

1. は じめに

エンドトキシン（細菌内毒素）の本態は，グラ ム陰性菌の細胞壁構成成分として不可欠なリポ多 糖（LPS）である。LPS は菌体表層に存在する が，その多糖部分が菌体の外側に伸長し，リピド A と呼ばれる脂質部分は脂質二重膜の構成要素 として膜構造中に組み込まれているため, この構 造は溶菌などによって菌体が破壊されないと完全 には暴露されない。リピド $\mathrm{A}$ の構造はグルコサ ミン二糖体骨格にリン酸基とアシル基が結合した 比較的単純な構造であるが, 古くからェンドトキ シン活性と呼ばれていた多彩な活性の大部分がこ の構造で発現されることが明らかになっている

\section{Motohiro MATSUURA}

The Role of Cytokines in Endotoxin Activities

Department of Microbiology, Jichi Medical School, Tochigi 329-04
$(23,31,38)$ 。エンドトキシンといら名の由来 は, 菌の培養ろ過液中ではなく, 菌体溶解液中に 強い活性が認められるため, 菌体内に保持されて いる毒素活性物質と考えられたことにあるが，現 在ではエンドトキシンの活性中心であるリピド A の性質を反映したものであることが理解でき る。

エンドトキシンによって発現される活性は多岐 にわたることが知られているが，何故この様に多 彩な活性が発現されるのであろらか。様々なグラ ム陰性菌由来の LPS の構造を比較してもリピド A 部分の構造は普遍性が高い。そのため生体に とっては感染などに際して接する機会の多い外来 構造であり，この様な構造を認識することにより 生体は感染に対する防御機構を進化させて来たの ではないだろらか。高度に進化した防御機構を有 する高等動物では, リピド A の様に普遍性の高 い外来構造に免疫細胞が応答し生体防御のための 
様々な反応を引き起こす。その際, 免疫細胞間の 反応を仲介し調節する物質として, 近年様々なサ イトカインの存在とそれらの機能が次々と明らか になってきている。エンドトキシンの多彩な活性 もエンドトキシン刺激により免疫細胞から産生放 出されるサイトカインの作用を介した活性として 説明できる部分がかなりあることが明らかになり つつある。本稿では, サイトカインの関与が明ら かになりつつあるエンドトキシン活性の代表的な 例をいくつか取り上げ，これまでの研究成果を紹 介したい。

\section{2. エンドトキシン刺激によって 誘導されるサイトカイン}

サイトカインは, 従来は, 免疫担当細胞である リンパ球やマクロファージが産生するタンパク性 の液性因子で，免疫応答や細胞の分化，増殖を調 節する物質とされていたが，研究が進むにつれ， 産生細胞の種類でも, 発現される活性でも, その 範囲が拡大されている。サイトカインの一般的な 性質として, 糖タンパク質であること, 極めて微 量で作用を発現すること，受容体を持った細胞に 作用すること, 単一のサイトカインが複数の作用 を示すこと，異なるサイトカインが共通の活性発 現作用を含むことなどがある。従って, 各サイト カインの作用は独立した作用であると同時に互い に関連し合い, サイトカインネットワークを形成 している。

エンドトキシンは多彩な活性を発現するが，そ れらの活性はェンドトキシンが標的細胞に作用し て直接発現される活性ではなく, エンドトキシン 刺激によって生体内で産生されるメディエーター 類の作用を介した活性であることが明らかになっ てきている。この様なメディエーター類として， 血小板活性化因子，プロスタグランジン，ロイコ トリエン, トロンボキサン, などのケミカルメデ ィエーター類と共にサイトカイン類が大きな役割 を担っている。エンドトキシン作用発現の仲介細 胞としてサイトカイン産生の中心的な役割を担っ ているのは単球・マクロファージ系細胞である が, 好中球, 血管内皮細胞, 線維芽細胞, 血小板, B 細胞なども応答細胞として働いていることが知 られている。しかし， T 細胞に対しては直接的に
作用しサイトカイン産生を誘導する活性は通常認 められない。従って，エンドトキシンの作用を仲 介するサイトカインとしては単球・マクロファー ジ系細胞から産生されるモノカイン類が主であ る。中でも TNF $\alpha$ (腫瘍壊死因子 $\alpha$ ) 及び IL-1 は 数多くの活性発現に中心的な役割を演じている

(13)。これらのサイトカイン以外にも IL-6, IL-8, IL-10, IFN (インターフェロン) , CSF（コロニー 刺激因子）などがエンドトキシン刺激によって産 生され活性発現に関与していることが知られてい る $(2,81)$ 。

エンドトキシンはグラム陰性菌感染に際して宿 主体内で遊離放出され, 宿主細胞がこのエンドト キシンを認識することにより防御活性の亢進のた めにサイトカインなどを産生すると考兄られる。 サイトカインは主として局所的に働き, 産生細胞 自身や近傍の細胞に作用することにより防御作用 を発現するが，局所で大量に産生された場合には 血中に放出され遠隔の臓器や組織に作用し, 障害 を与えてしまらこともある。エンドトキシンが生 体にとって有益な（防御的な）活性を示す一方, 生体にとって障害的な活性をも示すのは, 生体側 がェンドトキシンに過利に反応しやすく, 防御活 性を発現するためのメディエーター類産生の正常 なバランスが崩れ，障害的な活性の原因となる過 剰な反応を引き起こす様なメディエーター類産生 の異常へと傾きやすいためであるといら考学が一 般的に受け入れられている（図 1 )。

\section{3. 非特異的抵抗性増強作用とサイトカイン}

エンドトキシンを動物に投与するとその動物は 数時間後から種々の感染に対して抵抗性を示すよ らになる。この感染抵抗性は投与した LPS と感 染菌の間の特異性に関係なく発現される。即ち, 大腸菌由来の LPS を投与した場合でも, 大腸菌 以外のグラム陰性菌の感染に対する抵抗性をも付 与できるし，更に，LPS を菌体成分として含ま ないグラム陽性菌, 真菌, 寄生虫やウイルスの感 染に対してまで抵抗性を与えることができるので ある。この作用の発現には B 細胞や $\mathrm{T}$ 細胞の関 与はあまり認められないことが報告されて拉り

$(12,60)$, マクロファージ系細胞及び産生され るサイトカインの関与が考えられる。非特異的感 


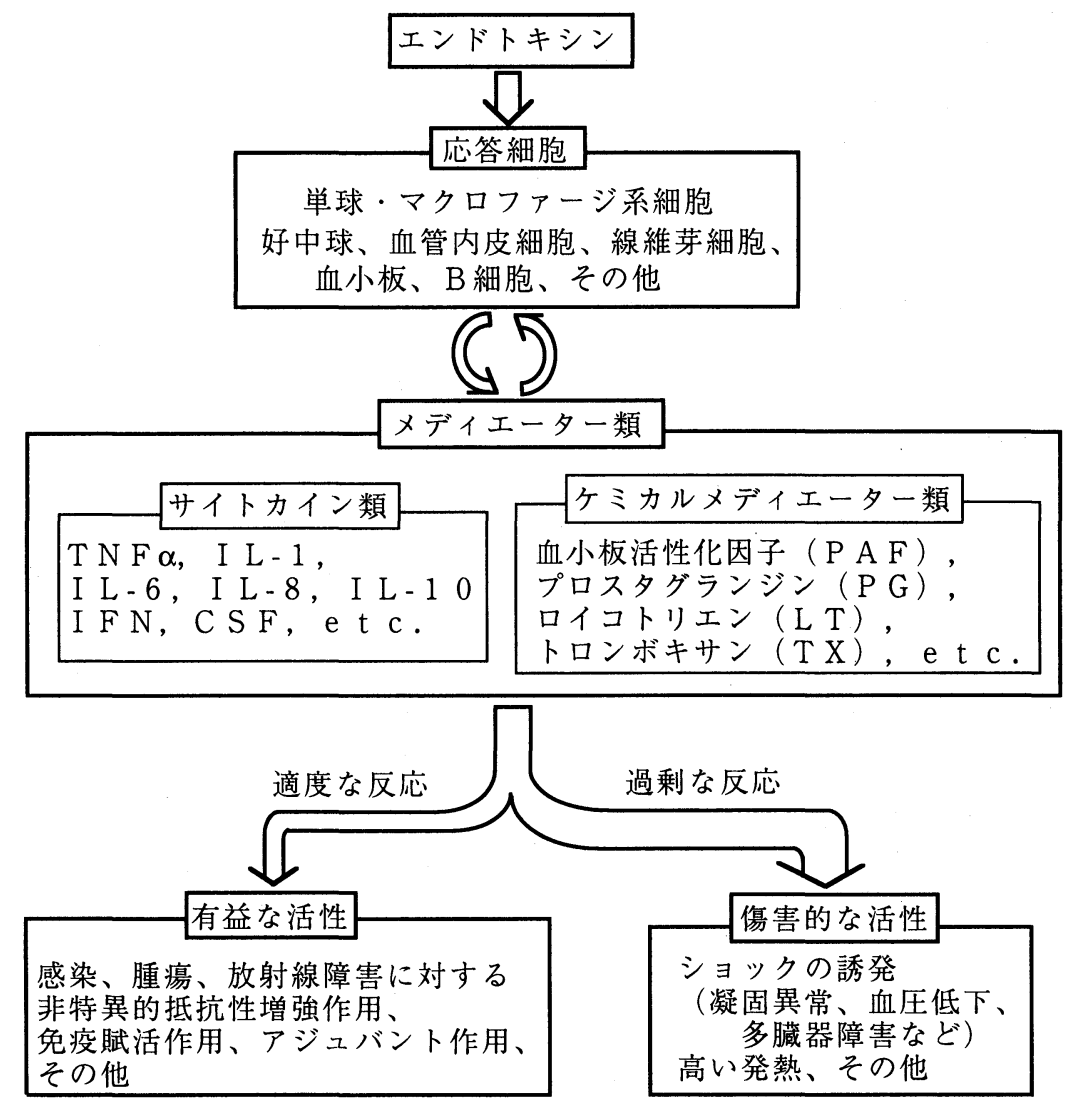

図 1.エンドトキシンの活性発現カスケード

染抵抗性の獲得には, 抗原刺激後, 抗体産生まで に要する様な長時間は必要なく, LPS 投与後 1 日以内の短時間で十分であり, 時間的な面からも サイトカインの産生を介した作用の関与が予想さ れる。実際, LPS 刺激によってマクロファージ 系細胞から産生されるサイトカイン類, TNF $\alpha$ $(17,63)$, IL-1 $(77,82)$, IL-8 (83) 户 CSF (21）を用いて，これらサイトカイン類が種々の 細菌や真菌, ウイルス, 寄生虫の感染に対して非 特異的に感染抵抗性を付与できることが報告され ている。

ところが LPS のこの作用は, これらのサイト カイン類を介した作用としてだけでは説明しきれ ず，それ以上に複雑な機構を含んでいると考えら れる。実験動物に LPS を繰り返し投与すると, サイトカイン類の産生に関しては 2 度目の LPS 投与以後は抑制（トレランス）を受けるが，感染
抵抗性増強作用は逆に強化されるのである。また， グルココルチコイドを投与して括くと LPS 投与 による TNF $\alpha$ や IL-1 の産生を抑制できるが，感 染抵抗性増強作用は抑制されないといら報告もあ る (59)。

感染以外にも腫瘍や放射線障害に対してもエン ドトキシンは抵抗性増強作用を付与できるが，抗 腫瘍活性に执いても TNF $\alpha$ を始めとするサイト カイン類の関与は大きいと考兄られている。放射 線障害に対する防御作用に関する研究では, LPS 投与により内因的に産生された TNF $\alpha$ および IL1 の関与が大きいことが報告されている（56）。

この様な LPS による非特異的抵抗性増強作用 は，外来構造を認識した生体細胞による防御機構 六進作用の一部に他ならないと考兄られるが，サ イトカインに依存した防御網の活性化だけに止ま らず，幾重にも張りめぐらされたその他の防御網 
の活性化にも依存しているため, サイトカインと いら側面からだけでは十分説明しきれない面が出 てくるのであろらと思われる。

\section{4. エンドトキシンショックとサイトカイン}

グラム陰性菌による菌血症や敗血症に際して は，その経過中に悪寒や発熱などを伴って突然シ ョック状態に陥ることがあり,グラム陰性菌性シ ョックと呼ばれている。このショックの病態は, エンドトキシンを動物に静注した時に起こるショ ック（エンドトキシンショック）の病態と極めて 相同性が高いことから, 感染菌から遊離したェン ドトキシンがグラム陰性菌性ショックの原因因子 であると考学られている。このショックの誘発は, 臨床上問題となる代表的なエンドトキシンの障害 作用であるが，この作用の発現にも数々のサイト カインが介在していることが明らかになって来て いる。特に, TNF $\alpha$ と IL-1 が中心的な役割を果 たしているとして注目されている $(9,13)$ 。以 下に各サイトカインについて, エンドトキシンシ ョックとの関連を述べる。

\section{(1) $\mathrm{TNF} \alpha$}

TNF $\alpha$ は， BCG 感染マウスにLPS を投与した 時, 単球・マクロファージ系細胞から血中に放出 され, MethA 肉腫に対して出血性壊死作用を示 す物質として1975年に Carswell ら（10）により 報告された。その後, この物質は腫瘍細胞に対す る壊死作用以外にも様々な活性を有するサイトカ インであることが分かってきた。エンドトキシン ショックとの関係についての最初の報告は1985 年に Beutler ら（7）によるものであった。この 報告では，抗マウス TNF 抗体を予め投与された マウスは致死量のエンドトキシンに対しても抵抗 性を獲得し生残できることを示した。次いで,リ コンビナント TNF $\alpha$ を投与された動物に, ショ ックや臓器障害などのエンドトキシンショック類

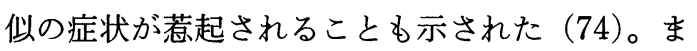
た， TNF $\alpha$ に対するモノクローナル抗体を用い て, 致死量の大腸菌をマウスに投与する敗血症性 ショックモデルでも抗 TNF 抗体が防御効果を発 現することが示された（75）。これらの結果より， エンドトキシンの作用により内因的に産生される $\mathrm{TNF} \alpha$ がエンドトキシンショックのメディエー
ターとして大きな働きをしていることが明らかに され, その後もこの関係に基づいた研究成果が数 多く報告されている。最近では TNFレセプター を欠損したノックアウトマウスが作成され，この マウスは $\mathrm{TNF} \alpha$ の致死毒性に対しても, 実験的 エンドトキシンシックの誘発に対しても，耐性を 示すことが報告された $(61,64)$ 。ただし，エン ドトキシンショックの発症機序の全てを $\mathrm{TNF} \alpha$ 単独の作用として説明できるものではない。 $\mathrm{TNF} \alpha$ による障害作用を増強する因子として, 他のサイトカイン類との相互作用 (86), 宿主の 被感染状態 (46) や微量のエンドトキシンの混 在（65）その他の多くの因子の関与が報告され ている。

エンドトキシンショックの発症には数多くの因 子が関与していると考学られるが，その因子の中 で中心的なメディェーターである $\mathrm{TNF} \alpha$ の作用 あるいは生体内での $\mathrm{TNF} \alpha$ の産生を抑えること によってショックの誘発を防止できる可能性が大 きい。この様な考えに基づいて, $\mathrm{TNF} \alpha$ の制御 によるェンドトキシンショックの誘発の防止を目 指した研究が進められている（表1）。コルチコ ステロイドやペントキシフィリン (Pentoxifylline）は TNF $\alpha$ の産生を抑制する作用を有する 薬剂で, エンドトキシンショックの治療への応用 が検討されている。また，毒性の高い通常のリピ ド A に対し，構造が少し変化することによって 毒性が大きく低下した低毒性リピド A あるいは リピド A 類縁化合物中に, エンドトキシンの拮 抗剤としてショックの防止に利用できる可能性の ある物が見出されている。これらの作用としてェ ンドトキシン刺激による $\mathrm{TNF} \alpha$ の産生を抑制す る機構の関与が認められている $(47,81,90) 。$ $\mathrm{TNF} \alpha$ は，その産生細胞内では $26 \mathrm{kDa}$ の前駆体 タンパク質として合成され，タンパク分解酵素に よる分解（プロセシング）を受けて $17 \mathrm{kDa}$ の成 熟 $\mathrm{TNF} \alpha$ として細胞外に放出され活性を発現す るが，このプロセシング酵素の阻害剤が最近見出 され，これら阻害剤の投与によりマウスでのエン ドトキシンショックの誘発が抑えられることが報 告された $(24,48,50)$ 。 $\mathrm{TNF} \alpha$ の活性発現の中 和を標的としたものとして, 抗 TNF $\alpha$ 抗体の利 用が動物実験の結果から期待され，ヒト型抗 
表 1. エンドトキシンショックに対する治療への応用が検討されている

主なサイトカイン抑制剂

\begin{tabular}{|c|c|c|}
\hline 抑制作用点 & 抑 制 剂 & $\begin{array}{c}\text { 抑制を受ける } \\
\text { 主なサイイン }\end{array}$ \\
\hline \multirow[t]{4}{*}{ 産生過程 } & コルチュステロイド & $\mathrm{TNF} \alpha$, IL-1 \\
\hline & ペントキシフィリン (Pentoxifylline) & $\mathrm{TNF} \alpha$ \\
\hline & 低毒性リピド A 類縁化合物 & $\mathrm{TNF} \alpha$ \\
\hline & 抑制性サイトカイン（IL-4, IL-10） & TNF $\alpha$, IL-1, IL-8 \\
\hline プロセシング過程 & $\mathrm{TNF} \alpha$ プロセシング酵素阻害剂 & $\mathrm{TNF} \alpha$ \\
\hline \multirow[t]{4}{*}{ 活性発現過程 } & 抗 $\mathrm{TNF} \alpha$ 抗体 & $\mathrm{TNF} \alpha$ \\
\hline & 可溶性 $\mathrm{TNF} \alpha$ 受容体（sTNFR） & $\mathrm{TNF} \alpha$ \\
\hline & 抗 IL-1 抗体 & IL-1 \\
\hline & IL-1 受容体拮抗物質（IL-1ra） & IL-1 \\
\hline
\end{tabular}

$\mathrm{TNF} \alpha$ モノクローナル抗体を作成し臨床試験が 行なわれている。また, 可溶性 TNF レセプター （sTNFR）は TNF $\alpha$ 受容体の細胞外ドメインが酵 素分解を受け, 細胞から遊離したものであるが, $\mathrm{TNF} \alpha$ そ結合しその活性を中和する。生体内で $\mathrm{TNF} \alpha$ が過剰に産生された時その調節物質とし て機能している可能性があり（5)，この STNFR をエンドトキシンショックの抑制に応用する研究 も進められている（79）。

\section{(2) IL-1}

IL-1 には $\alpha$ 型と $\beta$ 型の 2 種類があり, 構造的 には相違があるが，同一の受容体に結合し作用す るため，注涪同一の生物活性を示す。IL-1 は多 くの点で $\mathrm{TNF} \alpha$ と共通性のある生理活性を示し (40)，エンドトキシン投与や細菌感染に際して, $\mathrm{TNF} \alpha$ の産生に引き続いて多量に産生され血中 に放出されるサイトカインである（9)。IL-1 の 作用の一つとしてプラスミノーゲンアクチベー ターインヒビター (PAI)-1 の産生を誘導し, 局 所凝固能を元進するという報告がある（54）。ま た，リコンビナント IL-1 をウサギに全身投与す ることにより, ショック様症状が萀起されること が報告され（58）, IL-1 もエンドトキシンショッ クの誘発に重要な役割を果たすと考えられてい る。また, IL-1 が TNF $\alpha$ と相乗的に作用して, マウスに対する致死毒性を高めることも見出され た (86)。

興味あることに IL-1 に関連した物質として, IL-1 の活性を阻害する物質もエンドトキシンを 投与したヒト血清中（15）や発熱患者の尿中
（42）に存在することが見出された。この物質 が単離されその cDNA も明らかにされ (18), IL-1 と競合して IL-1 受容体に結合するがシグナ ルは伝えないため IL-1 の活性発現を阻害する物 質であることが判明し，IL-1 受容体拮抗物質 （IL-1ra）と呼ばれるよらになった。この IL-1ra を利用して IL-1 受容体の機能を抑制することに よりエンドトキシンショックや敗血症性ショック の誘発を軽減できることが示され（20，57，87）, 治療薬としての可能性が注目されている。IL-1ra は IL-1 の産生に引き続いて産生され，IL-1 の過 剰な産生に対して抑制をかけるための生体内の調 節物質と考えられる。更に興味深いことには抑制 性サイトカインである IL-4 や IL-10 は，LPS 刺 激によるヒト単球からの IL-1 や TNF $\alpha$ などの産 生に対しては抑制をかけるが，IL-1ra の産生は 促進する作用を有していることが報告されて拉り

$(19 ， 25 ， 32)$ ，サイトカインネットワークの巧 妙な調節機構の一端がうかがえる。

$\mathrm{TNF} \alpha$ の場合と同様，IL-1 を抑制することに よりェンドトキシンショックに対する防御を目指 す研究も, IL-1 の産生抑制, プロセッシング酵 素の阻害剤, 抗体や可溶性受容体による活性の中 和及び上述の IL-1ra による受容体拮抗作用など を標的として様々な角度から進められている（表 1 )。

\section{(3) IL-6}

血中 IL-6 濃度の上昇と敗血症の発症あるいは ショックによる死亡との間に相関が認められるこ とより $(26,80,87)$ エンドトキシンショック 
の誘発への IL-6 の関与が考兄られた。他方, ヒ 卜単球を用いた in vitro の実験では，エンドトキ シン刺激による TNF $\alpha$ や IL-1 の産生に対して IL-6 は抑制効果を示すとの報告 $(1,66)$ や，リ コンビナント IL-6 をイヌに投与してもショック の時に見られる血圧低下や内皮細胞の障害などの 病状が認められないとの報告（62）があり，エ ンドトキシンショックの誘発に IL-6 が積極的に 関与しているのかどうかについて疑問が持たれ た。また，IL-6 に対する抗体や IL-6 受容体を用 いた研究 $(28 ， 43 ， 70)$, 並びに IL-6 遺伝子の ノックアウトマウス（IL-6 を産生できない）を 用いた研究 (39) から, 敗血症やエンドトキシ ンショックの誘発に対する IL-6 の関与は部分的 なものである可能性が示唆された。チンパンジー を実験動物として抗 IL-6 モノクローナル抗体を 用いた研究から，IL-6 は軽度のエンドトキシン 血症に打ける凝固系の活性化にはメディエーター として重要な役割を果たしているが，エンドトキ シン投与による他のサイトカイン類（TNF $\alpha$ や IL-1 など）の産生放出に対する増幅効果や好中 球増多及び脱顆粒効果の発現には関与していない ことが報告された（78）。この様にエンドトキシ ンショックに対する IL-6 の関与は TNF $\alpha$ や IL-1 の様に全体的なものではなくある範囲に限られた 部分的なものであると考えられている。

\section{(4) $\mathrm{IFN} \gamma$}

このサイトカインもェンドトキシンショックの 誘発に関与していることが，エンドトキシンを投 与されたヒトや動物で $\mathrm{IFN} \gamma$ の産生が認められる こと（85）や，マウスを用いたェンドトキシン ショックのモデル実験系で抗 IFN $\gamma$ 抗体がショッ クの抑制効果を示すこと（27，29）などから示 唆された。また, 最近では IFN $\gamma$ レセプターを欠 損したノックアウトマウスが作成され，このマウ スが敗血症やェンドトキシンによるショックの誘 発に抵抗性を示すことが見出されている（11， $34)$ 。

$\mathrm{IFN \gamma}$ はマクロファージ活性化因子としての役 割を担ったサイトカインでT細胞や NK 細胞から 産生されることが知られているが, LPS がこれ ら細胞に直接作用して IFN $\gamma$ を産生させる作用は 認められていない。LPS 刺激による IFN $\gamma$ の産生
に関しては, in vitro の実験では, マウスの脾細 胞を LPS 無添加で $1-3$ 日間培養後 LPS で刺激 すると IFN $\gamma$ が産生されるという報告があり (8)， この機構として, IL-2 刺激を受けた $\mathrm{T}$ 細胞に LPS が作用すると IFN $\gamma$ 産生を誘導できる可能性 が示されている。LPS 刺激による IFN $\gamma$ の産生機 構は解明されていないが, 上述の様に LPS を動 物に投与する in vivo の実験では, 生体内で IFN が産生されその作用を発現するものと考兄られる。 $\mathrm{TNF} \alpha$ や IL-1 などの様に, LPS が単球・マク口 ファージ系細胞などに作用して直接的にサイトカ インの産生を誘導する機構とは異なり, $\mathrm{IFN} \gamma$ 産 生の場合には, 複数の細胞種やメディエーター類 を介した間接的な機構で LPS が IFN $\gamma$ の産生を 誘導しているのではないかと考えられる。

$\mathrm{IFN} \gamma$ はマクロファージ活性化作用を有し, LPS 刺激によるマクロファージからの $\mathrm{TNF} \alpha$ の 産生を増強する。この $\mathrm{TNF} \alpha$ 産生増強作用がェ ンドトキシンショックの誘発に拈ける IFN $\gamma$ の主 な役割と考兄られるが，更に， IFN $\gamma$ は TNF $\alpha$ の 作用を介さない機構でも敗血症やエンドトキシン ショックの誘発に関与している可能性があると報 告されている $(34,37,69) 。$

(5) その他のサイトカイン

IL-8 もエンドトキシン刺激に応じて産生され 急性期反応に重要な役割を演じていると報告され ている (22)。IL-8 は好中球走化因子として発見 され, 感染に伴って炎症局所へ好中球を集積させ 活性化させる防御因子としての役割を担っている と考兄られている。活性化された好中球は感染菌 を破壊するために中性プロテアーゼや活性酸素を 産生する。ところがェンドトキシン刺激により高 サイトカイン血症が引き起こされた場合, 過剩に 産生された IL-8 が好中球の活性化を過渡に充進 させ, 中性プロテアーゼや活性酸素を大量に産生 放出させてしまい, 周辺臓器の重要なタンパク質 にまで作用し变性させてしまらため, ェンドトキ シンショック時の臓器障害の原因となる可能性が 考えられている。

感染や炎症の局所に集積した防御細胞をその場 飞止めて括く作用を有する因子と考光られる MIF (Migration inhibitory factor) もエンドトキ シンショックの発症に関与している可能性が報告 
されている(6)。

他方，エンドトキシンショックを防止しよらと する方向で働くサイトカイン類も同時に産生され ている。前述の IL-1ra もとの一種と考兄られる が，抑制性サイトカインとしての作用が知られて いる IL-10 も LPS 刺激により産生されショック の誘発に対して抑制的に働いていると思われる。 実験動物に IL-10 を投与することにより，エンド トキシンショックからの回避が認められること (25，32）や，IL-10 に対するモノクローナル抗 体を投与することによりェンドトキシンショック に対する動物の感受性が上昇することなどが報告 されている $(33,44)$ 。また, $\operatorname{IFN} \alpha$ も $\mathrm{TNF} \alpha$ 産 生を抑制し，エンドトキシンショックを阻止でき るといら報告もある（76）。

\section{5. 発熱性とサイトカイン}

エンドトキシンの強い発熱性はその発見当初よ り特徵的な活性の一つとして知られていたが，こ の活性もリピド A 部分によって担われているこ とが明らかになっている $(23,31,38)$ 。発熱性 の研究には主としてウサギが使われるが，エンド トキシン投与後に採取したウサギの血清を他のウ サギに投与すると, そのウサギは発熱を起こすこ とが明らかになった（3）。この血清中には白血 球の培養液中に産生される発熱物質と同じ物質が 存在することが示唆され，エンドトキシンの様に 体外から投与した物質を外因性発熱物質と呼ぶの に対し, 内因性発熱物質 (endogenous pyrogen, EP）と呼ばれるようになった。エンドトキシン の様な外因性発熱物質は, 宿主の白血球を活性化 し，EP の産生を誘導し，産生された EP が循環 血液中に放出されることによって, 発熱作用を引 き起こすと考兄られるよらになった。この EP の 本態の解明に向けて研究が進められた。その結果, 別の観点から研究が進んできた IL-1 が LPS 投与 による発熱作用を仲介する EP として最初に同定 された $(4,53)$ 。IL-1 以外にも発熱性を示すサ イトカインが種々存在することが明らかになり,

現在では, EP は外因性発熱物質の刺激により体 内で産生される発熱性サイトカインの混合物の総 称と理解されている。従って, 外因性発熱物質の 種類によって EP 中に含まれる発熱性サイトカイ
ンの種類や組み合わせも異なるが，エンドトキシ ンを投与した場合には EP として IL-1 以外にも IL-6 (36, 41), TNF $\alpha(36,84), \operatorname{IFN}(14,35$, 52）が関与していることが示唆されている。ま た, これら発熱性サイトカイン類も直接的な発熱 刺激物質ではなく，プロスタグランジンが最終的 な発熱の刺激伝達物質であることが明らかにされ ている (49，51)。ただし，IL-8 はプロスタグラ ソジン非依存的に発熱作用を発現する可能性が最 近になって報告された（89）。

発熱反応が更に複雑な事には, この反応には脳 が関与していると考えられるが，サイトカイン類 は血管・脳関門を通過できないといら事がある。 LPS や IL-1 $\beta$ あるいはインドメタシン（プロス タグランジンの合成を抑える解熱剤）などを，静 脈内や皮下から投与する他に，脳室内に投与する 系を組み合わせて発熱反応に関する研究が進めら れている。LPS を投与すると，通常，投与後 60 分付近及び 180 分付近に 2 相性のピークを持つ発 熱パターンを示すが, LPS の量が不十分な時に は最初の60分付近のピークのみを有する 1 相性 の発熱パターンを示すことが知られている。これ ら各々のピークの発熱機構に関する検討から，第 1 相目のピークは血液側からだけ接近できる部位 でのプロスタグランジンの産生放出に起因して抒 り, 第 2 相目のピークは血液側と脳室側のイン ターフェイスと考えられる部位での IL- $\beta$ の産生 を介したプロスタグランジンの産生放出が関与し ていることが示唆されている（55）。

この様にエンドトキシンによる発熱機構に関し ても研究の進展が見られるが, 発熱そのものの生 理学的意義についても研究が進んでいる。エンド トキシンは注射剤などへの混入を避けねばならな い代表的な発熱物質であり, 発熱作用は生体に対 する障害的な作用であると単純に考学られがちで あるが，適度な発熱は生体が通常より少し高いレ ベルに体温を調節している状態で, 生体機能を活 性化し, 非特異的防御反応の充進とも関連した, 生体にとって有益な反応であることが明らかにな ってきている。もちろん，エンドトキシンは生体 の温度調節機能を上回る過度の発熱を誘発し, 生 体に対する障害的な作用を発現する危険性のある 物質であることにはちがいはない。 


\section{6. サイトカイン産生のための細胞活性化機構}

これまでに述べてきたように LPS 刺激を受け て様々なサイトカイン類を産生放出する主要な細 胞はマクロファージ系細胞である。LPS による マクロファージ活性化機構について最近研究が急 速に進んでいる。マクロファージ活性化のために はまず LPS のマクロファージへの結合が必要で あるが，この結合に関与する 2 種類のタンパク 質が見出された。そのタンパク質の一つは，感染 後の急性期の血墏中に増加し, LPS と強い結合 性を示すタンパク質であり LBP (LPS binding protein) と名付けられた $(67,72)$ 。LBP は単独
ではマクロファージと結合できないが，LPS の リピド A 部分と結合し (73), LPS-LBP 複合体 を形成するとマクロファージに結合できるように なり，LPS によるマクロファージの活性化（サ イトカイン産生）を著しく増強する作用を有する ことが明らかになった（45）。もら一つのタンパ ク質は，マクロファージの分化抗原の一種である CD14 で，このタンパク質が LPS-LBP 複合体を 結合するマクロファージ側の受容体であることが 明らかになった (88)。抗CD14抗体が LPS-LBP 複合体によるマクロファージからの TNF 産生を 阻害できることも示された。この様な結果から LPS はまず血液中の LBP と結合し LPS-LBP 複

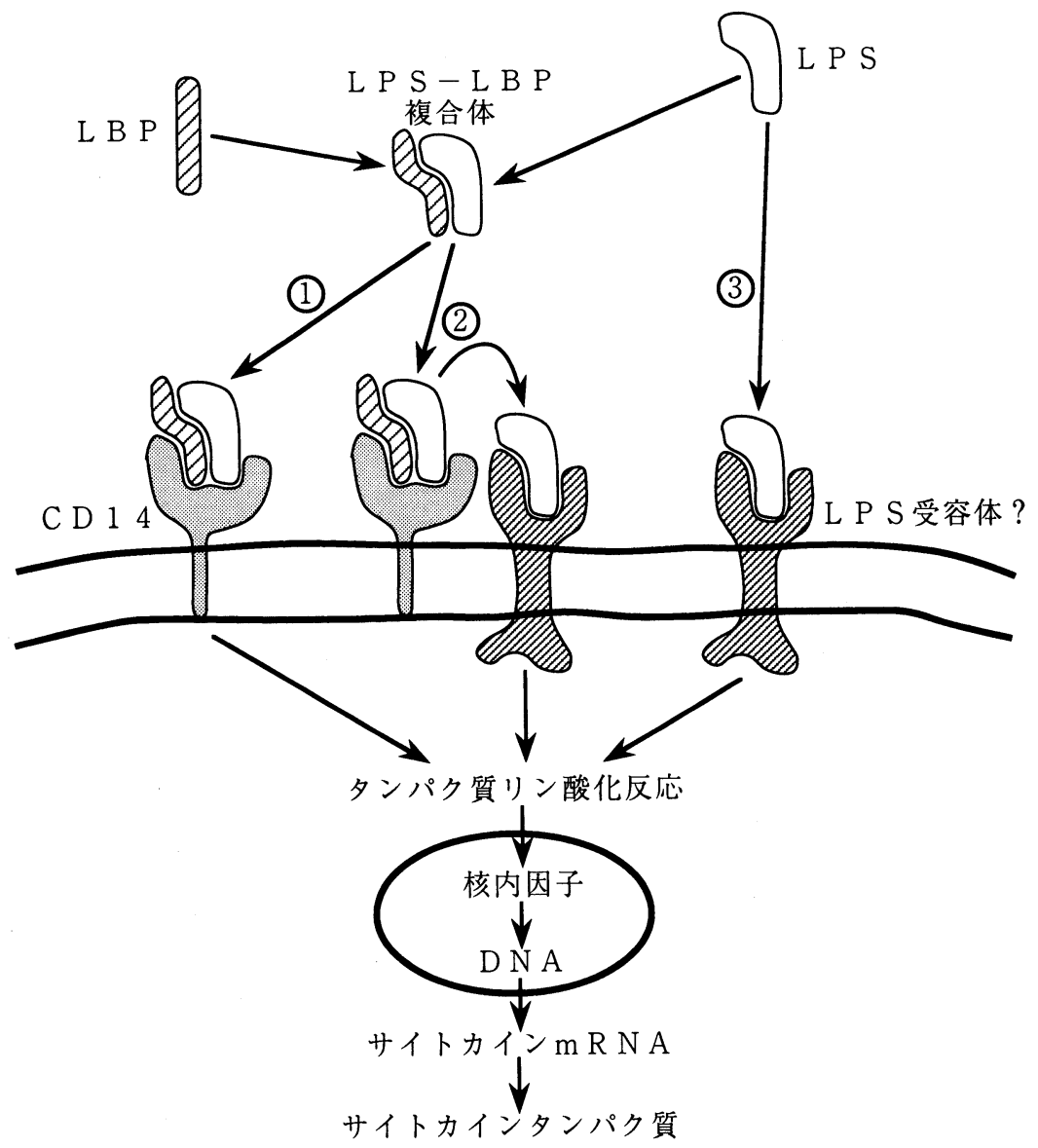

図 2. LPS 刺激によるマクロファージ活性化の想定機構

現在のところ，以下の 3 つのケースが考えられている。(1)LPS-LBP 複合体が結合した CD14 から直接細胞質内へ 刺激が伝達される，(2)CD14 に結合した LPS-LBP 複合体から，細胞質内へ刺激を伝達する別の LPS 受容体へ LPS が移転する，(3)LPS が CD14 とは異なる LPS 受容体へ直接結合し細胞質内へ刺激が伝達される。 
合体を形成し，その後，マクロファージ表面の CD14 と結合することによりマクロファージを活 性化し, サイトカイン産生を誘導する経路がある ことが示された。

CD14 はそのペプチドの C 末端に結合した GPI アンカーと呼ばれる糖脂質によってマクロファー ジの膜に結合して括り，細胞質側にはドメインを 持たないため, CD14 が直接細胞内にシグナルを 伝える可能性は少なく, 他の分子の関与が推察さ れる。CD14 はチロシンキナーゼ p53/56 lyn と複 合体を形成することが報告されて拈り (71)，こ のチロシンキナーゼが LPS の情報伝達に関与し ているのかどうかについて現在関心が高まってい るところである。細胞内情報伝達系では刺激を受 けたレセプターに連動してタンパク質キナーゼが 活性化され，タンパク質のリン酸化を介して核内 因子を活性化し，DNA に作用し，mRNAの発現 を誘導し，最終的にサイトカインなどの産生に至 る経路が考えられている。LPS でマクロファー ジを刺激した場合, LPS 応答性細胞でだけ認め られる細胞内タンパク質リン酸化反応の克進が見 出されて括り（68），チロシンキナーゼを含むキ ナーゼ類の活性化が CD14 以後の情報伝達系に関 与している可能性が考兄られている。

CD14 Æへた系では, 1-10 ng/ml の低濃度の LPS の刺激を伝達できるが，高濃度の LPS (100-1000 ng/ml) による刺激伝達では LBP にも CD14 にも依存しない経路があることが示唆され ている (30)。発作性夜間へモグロビン尿症の患 者はCD14を欠損していることが明らかになって いるが，その血液単球は低濃度の LPS には反応 せず, 高濃度の LPS にしか応答を示さないと報 告されている(16)。その他の CD14 を発現して いない細胞でも同様の応答性が観察されている。 この事は, LPS が高濃度で作用する場合には CD14 以外の受容体に LPS が結合する可能性を 示唆するものである。CD14 を介する経路でも，

LPS-LBP が CD14 に結合後, LPS は別のシグナ ル伝達分子に転移される可能性があり, その分子 が高濃度 LPS が直接結合する分子と同一の, キ ナーゼ活性化機能を有する, 真の LPS レセプター であるかもしれない。現在, この様な機能を担っ た LPS レセプターの解明に向けて活発に研究が
進められているところである。これらの結果から， 現在考えられている LPS によるマクロファージ 活性化機構のモデルを図 2 に示した。LPS 刺激 によって同一のマクロファージから様々なサイト カインが産生されるが, 個々のサイトカイン産生 のための刺激伝達がどの様に相互に関連して伝わ って行くのかに関しては未だほとんど分かってい ない。

\section{7.おわりに}

この総説では, エンドトキシンの代表的な活性 を取りあげ，各活性毎にサイトカインの関与を述 べてきた。ところが，同一のサイトカインが複数 の活性発現にもまたがって関与しているので, 表 2 にェンドトキシン刺激によって産生されるサイ トカイン毎に, エンドトキシン活性への関与をま とめてみた。即ち, エンドトキシンの多彩な活性 から個々の活性を取り出して見ても, 複数のサイ トカインがその活性発現に関与して拈り，また， 個々のサイトカインを取り上げて見ても，複数の 活性発現に関与しているといらことである。この 様にサイトカインを始めとする多数のメディエー ターが打互に複雑に絡まり合ってェンドトキシン の活性発現に関与していることが明らかになって いる。サイトカインは生体側の細胞によって産生 される内因性産物であることを考えると，その本 来の役割は自己を防御するために働く物質であ り，積極的に自己に攻撃を加兄障害的な作用を発 揮する役割を担った物質であるとは考学られな い。ところがエンドトキシンショックの際などに は, 高サイトカイン血症を伴って生体に障害的な 作用を及ぼすのである。サイトカイン本来の役割 が産生細胞周辺での局所の作用であるといら考乒 からすれば，流血中に検出されるほどの多量のサ イトカインの産生放出は異常な事態である。単純 に考えると, 適量のサイトカインの産生は生体に とって有益な作用を誘導し, 過剩な産生は障害的 な作用の誘導に結びつくと考えられる。ただし， 単に量的な基準だけで判断できるものではなく， 標的細胞の種類やサイトカイン相互の量的関係な ぞを総合的に考慮する必要があるようである。

生体はサイトカインネットワークを始めとし， 多種のメディエーターを介する複雑で精巧な調節 
表 2. エンドトキシン刺激によって産生される主要なサイトカインと

それらサイトカインが関与する主なェンドトキシン活性

\begin{tabular}{|c|c|c|}
\hline サイトカイン & 有益な活性 & 障害的な活性 \\
\hline $\mathrm{TNF} \alpha$ & $\begin{array}{l}\text { 抗腫瘍活性 } \\
\text { 感染抵抗性増強作用 } \\
\text { 放射線抵抗性 }\end{array}$ & $\begin{array}{l}\text { ショックの誘発 } \\
\text { 発熱性 }\end{array}$ \\
\hline IL-1 & $\begin{array}{l}\text { 抗腫瘍活性 } \\
\text { 感染抵抗堌強作用 } \\
\text { 放射線抵抗性 }\end{array}$ & $\begin{array}{l}\text { 発熱性 } \\
\text { ショックの誘発 }\end{array}$ \\
\hline IL-6 & 抗体産生促進作用 & $\begin{array}{l}\text { 凝固異常の誘発 } \\
\text { 発熱性 }\end{array}$ \\
\hline IL-8 & 感染抵抗性増強作用（好中球走化活性） & 組織障害 \\
\hline IL-10 & 炎症性サイトカインの抑制 & \\
\hline $\operatorname{IFN} \alpha / \beta$ & 抗ウイルス作用 & 発熱性 \\
\hline $\mathrm{CSF}$ & 感染抵抗性増強作用（細胞増殖促進作用） & \\
\hline
\end{tabular}

を受けた生体防御網を発達させているが，エンド トキシンが障害的な作用を発現する場合には，こ の防御網の調節機構になんらかの狂いを生じさ せ, 異常な反応の暴走に霜止めをかけられなくし, サイトカインの産生バランスなどにも異常を引き 起こすものと考兄られる。現在, 過剩なサイトカ インの作用を抑制することでェンドトキシンショ ックに対する治療を目指す数々の研究が進んでい ることを紹介したが, 将来, 上述の調節機構の擋 乱作用に関する研究が進み, それを回避する方法 が明らかになれば，ょり根本的な面からの問題解 決ができるし，エンドトキシンの有益な活性だけ を効果的に発現させる方法の進展にも結びつくも のと考兄られる。

\section{文献}

1) Aderka, D., Le, J., Vilcek, J. (1989): IL-6 inhibits lipopolysaccharide-induced tumor necrosis factor production in cultured human monocytes U937 cells and mice. J. Immunol. 143, 3517-3523.

2) Andersson, J., Nagy, S., Bjork, L., Abrams, J., Holms, S., Andersson, U. (1992): Bacterial toxininduced cytokine production studies at the singlecell level. Immunol. Rev. 127, 69-96.

3) Atkins, E., Wood Jr.W.B. (1955): Studies on the pathogenesis of fever. I. The presence of transferable pyrogen in the blood stream following the injection of typhoid vaccine. J. Exp. Med. 101:
519-528.

4) Auron, P.E., Webb, A.C., Rosenwasser, L.J., Mucci, S.F., Rich, A., Wolff, S.M., Dinarello, C.A. (1984): Nucleotide sequence of human monocyte interleukin-1 precursor cDNA. Proc. Natl. Acad. Sci. USA 81: 7909-7911.

5) Bemelmans, M.H.A., Gouma, D.J., Buurman, W.A. (1993): LPS-induced sTNF-recepror release in vivo in a murine model: Investigation of the role of tumor necrosis factor, IL-1, leukemia inhibiting factor, and IFN- $\gamma$. J. Immunol. 151, 5554-5562.

6) Bernhagen, J., Calandra, T., Mitchell, R.A., Martin, S.B., Tracey, K.J., Voelter, W., Manogne, K.R., Cerami, A., Bucale, R. (1993): MIF is a pituitary-derived cytokine that potentiates lethal endotoxaemia. Nature 365, 756-759.

7) Beutler, B., Milsark, I.W., Cerami, A.C. (1985): Passive immunization against cachectin/tumor necrosis factor protects mice from lethal effect of endotoxin. Science 229, 869-871.

8) Blanchord, D.K., Djeu, J.Y., Klein, T.W., Friedman, H., Stewart II, W.E. (1986): Interferon- $\gamma$ induction by lipopolysaccharide: Dependence on interleukin 2 and macrophages. J. Immunol. 136, 963-970.

9) Cannon, J.G., Tompkins, R.G., Gelfand, J.A., Michie, H.R., Stanford, G.G., Van der Meer, J.W.M., Endres, S., Lonnemann, G., Corsetti, J., Chernow, B., Wilmore, D.W., Wolff, S.M., Burke, J.F., Dinarello, C.A. (1990): Circulating interleukin-1 and tumor necrosis factor in septic 
shock and experimental endotoxin fever. J. Infect. Dis. 161, 79-84.

10) Carswell, E.A., Old, L.J., Kassel, R.L., Green, S., Fiore, N., Williamson, B. (1975): An endotoxin-induced serum factor that causes necrosis of tumors. Proc. Natl. Acad. Sci. USA 72, 3666-3670.

11) Car, B.D., Eng, V.M., Schnyder, B., Ozmen, L., Huang, S., Galley, P., Heumann, S., Aguet, M., Ryffel, B. (1994): Interferon- $\gamma$ receptor deficient mice are resistant to endotoxin shock. J. Exp. Med. 179, 1437-1444.

12) Chedid, L., Parant, M., Damais, C., Parant, F., Juy, D., Galelli, A. (1976): Failure of endotoxin to increase nonspecific resistance to infection of lipopolysaccharide low-responder mice. Infect. Immun. 13, 722-727.

13) Dinarello, C.A. (1991): The proinflammatory cytokines interleukin-1 and tumor necrosis factor and treatment of the septic shock syndrome. J. Infect. Dis. 163, 1177-184.

14) Dinarello, C.A., Bernheim, H.A., Duff, G.W., Le, H.V., Nagabhushan, T.L., Hamilton, N.C., Coceani, F. (1984): Mechanisms of fever induced by recombinant humen interferon. J. Clin. Investi. 74: 906-913.

15) Dinarello, C.A., Rosenwasser, L.J., Wolff, S.M. (1981): Demonstration of a circulating supressor factor of thymocyte proliferation during endotoxin fever in humans. J. Immunol. 127, 2517-2519.

16) Duchow, J., Marchant, A., Crusiaux, A., Husson, C., Alonso-Vega, C., De Groote, D., Neve, P., Goldman, M. (1993): Imparied phagocyte responses to lipopoly-saccharide in paroxysmal nocturnal hemoglobinuria. Infect. Immun. 61, 4280-4285.

17) Echtenacher, B., Falk, W., Mannel, D.N., Krammer, P.H. (1990): Requirement of endogenous tumor necrosis factor/ cachectin for recovery from experimental peritonitis. J. Immunol. 145, 3762-3766.

18) Eisenberg, S.P., Evans, R.J., Arend, W.P., Verderber, E., Brewer, M.T., Hannum, C.H., Thompson, R.C. (1990): Primary structure and functional expression from complementary DNA of a human interleukin-1 receptor antagonist. Nature 343, 341-346.

19) Fenton, M.J., Buras, J.A., Donnelly, R.P. (1992): IL-4 reciprocally regulates IL-1 and IL-1 receptor antagonist expression in human monocyte. J. Immunol. 149, 1283-1288.
20) Fisher, E., Marano, M.A., Van Zee, K.J., Rocks, C.S., Hawes, A.S., Thompson, W.A., DeForge, L., Kenney, J.S., Remick, D.G., Bloedow, D.C., Thompson, R.C., Lowry, S.F., Moldawer, L.L. (1992): IL-1 receptor blockade improves survival and hemodynamic performance in $E$. coli septic shock, but fails to alter host response to sublethal endotoxemia. J. Clin. Invest. 89, 1551-1557.

21) Freund, M., Kleine, H,-D. (1992): The role of GMCSF in infection. Infection 20 (suppl. 2), S84-S92.

22) Fujishima, S., Hoffman, A.R., Vu, T., Kim, K.J., Zheng, H., Daniel, D., Kim, Y., Wallace, E.F., Larrick, J.W., Raffin, T.A. (1993): Regulation of neutrophil interleukin 8 gene expression and protein secretion by LPS, TNF- $\alpha$ and IL- $1 \beta$. J. Cell. Physiol. 154, 478-485.

23) Galanos, C., Luderitz, O., Rietschel, E. T., Westphal, O., Brade, H., Brade, L., Freudenberg, M., Schade, U., Imoto, M., Yoshimura, H., Kusumoto, S., Shiba, T. (1985): Synthetic and natural Escherichia coli free lipid A express identical endotoxic activities. Eur. J. Biochem. 148: 1-5.

24) Gearing, A.J.H., Beckett, P., Christodoulou, M., Churchill, M., Clements, J., Danidson, A.H., Drummond, A.H., Galloway, W.A., Gilbert, R., Gordon, J.L., Leber, T.M., Mangan, M., Miller, K., Nayee, P., Owen, K., Patel, S., Thomas, W., Wells, G., Wood, L.M., Woolley, K. (1994): Processing of tumor necrosis factor- $\alpha$ precursor by methalloproteinases. Nature 370, 555-557.

25) Gerard, C., Bruyns, C., Marchant, A., Abramowicz, D., Vandenabeele, P., Delvaux, A., Fiers, W., Goldman, M., Vela, T. (1993): Interleukin 10 reduces the release of tumor necrosis factor and prevents lethality in experimental endotoxemia. J. Exp. Med. 177, 547-550.

26) Hack, C.E., De Groot, E.R., Felt-Bersman, J.F., Nuijens, J.H., Strack Van Schijndel, R.J.M., Eerenberg-Belmer, A.J.M., Thijs, L.G., Aarden, L.A. (1989): Increased plasma levels of interleukin-6 in sepsis. Blood 74, 1704-1710.

27) Heinzel, F.P. (1990): The role of IFN $\gamma$ in the pathology of experimental endotoxemia. J. Immunol. 145, 2920-2924.

28) Heremans, H., Dillen, C., Put, W., Van Damme, J., Billiau, A. (1992): Protective effect of anti-interleukin (IL)-6 antibody against endotoxin, associated with paradoxically increased IL-6 levels. Eur. J. Immunol., 22, 2395-2401. 
29) Heremans, H., Van Damme, J., Dillen, C., Dijkmans, R., Billiau, A. (1990): Interferon- $\gamma$, mediator of lethal lipo-polysaccharide-induced Schwartzman-like shock reactions in mice. J. Exp. Med. 171, 1853-1869.

30) Heumann, D.H., Gallay, P., Barras, C., Zaech, P., Ulevitch, R.J., Tobias, P.S., Glauser, M.-P., Baumgartner, J.D. (1992): Control of lipopolysaccharide (LPS) binding and LPS-induced tumor necrosis factor secretion in human peripheral blood monocytes. J. Immunol. 148, 3505-3512.

31) Homma, J.Y., Matsuura, M., Kanegasaki, S., Kawakubo, Y., Kojima, Y., Shibukawa, N., Kumazawa, Y., Yamamoto, A., Tanamoto, K., Yasuda, T., Imoto, M., Yoshimura, H., Kusumoto, S., Shiba, T. (1985): Structural requirements of lipid A responsible for the functions: A study with chemically synthesized lipid A and its analogues. J. Biochem. 98: 395-406.

32) Howard, M., Muchamuel, T., Andrade, S., Menson, S. (1993): Interleukin 10 protects mice from lethal endotoxemia. J. Exp. Med. 177, 1205-1208.

33) Ishida, H., Hastingo, R., Thompson-Snipes, L., Howard, M. (1993): Modified immunological status of anti- IL-10 treated mice. Cell Immunol. 148, 371-384.

34) Kamijyo, R., Le, J., Shapiro, D., Havell, E.A., Huang, S., Aguet, M., Basland, M., Vilcek, J. (1993): Mice that lack the interferon- $\gamma$ receptor have profoundly altered responses to infection with Bacillus Calmette-Guerin and subsequent challenge with lipopolysaccharide. J. Exp. Med. 178, 1435-1440.

35) Kawasaki, H., Moriyama, M., Tanaka, A. (1987): Augumentation of endotoxin fever by recombinant human beta interferon in rabbits. Infect. Immun. 55: 1121-1125.

36) Klir, J.J., Roth, J., Szelenzi, Z., McCellan, J.L., Kluger, M.J. (1993): Role of hypothalamic interleukin-6 and tumor necrosis factor- $\alpha$ in LPSfever in rat. Am. J. Physiol., 265: R512-R517.

37) Kohler, J., Heumann, D., Garotta, G., LeRoy, D., Bailat, S., Barras, C., Baumgarten, J.-D., Glauser, M.P. (1993): IFN- $\gamma$ involvement in the severity of Gram-negative infections in mice. J. Immunol. 151, 916-921.

38) Kotani, S., Takada, H., Tsujimoto, M., Ogawa, T., Takahashi, I., Ikeda, T., Otsuka, K., Shimauchi, H., Kasai, N., Mashimo, J., Nagao, S., Tanaka, A.,
Tanaka, S., Harada, K., Nagai, K., Kitamura, H., Shiba, T., Kusumoto, S., Imoto, M., Yoshimura, H. (1985): Synthetic lipid A with endotoxic and related biological activities comparable to those of a natural lipid A from an Escherichia coli Re-mutant. Infect. Immun. 49: 225-237.

39) Kopf, M., Baumann, H., Freer, G., Freudenberg, M., Lamers, M., Kishimoto, M., Zinkernagel, R., Bleuthmann, H., Kohler, G. (1994): Impaired immune and acute-phase responses in inter-leukin-6deficient mice. Nature 368, 963-970.

40) Le, J., Vilcek, J. (1987): Tumor necrosis factor and interleukin-1: cytokines with multiple overlapping biological activities. Lab. Invest. 56, 234-248.

41) Lemary, L.G., Vander, A.J., Kluger, M.J. (1990): Role of interleukin- 6 in fever in rats. Am. J. Physiol. 258: R798-R803.

42) Liao, Z., Grimshaw, R.S., Rosenstreich, D.L. (1984): Identification of a specific interleukin-1 inhibitor in the urine of febrile patients. J. Exp. Med. 159, 125-126.

43) Libert, C., Vink, A., Coulie, P., Brouckaert, P., Everaerdt, B., Van Snick, J., Fiers, W. (1992): Limited involvement of interleukin-6 in the phathogenesis of lethal septic shock as revealed by the effect of monoclonal antibodies against interleukin-6 or its receptor in various murine models. Eur. J. Immunol. 22, 2625-2630.

44) Marchant, A., Bruyns, C., Vandenabeele, P., Ducarme, M., Gerard. C., Delvaux, A., De Groote, D., Abramowicz, D., Velu, T., Goldman, M. (1994): Interleukin-10 controles interferon- $\gamma$ and tumor necrosis factor production during experimental endotoxemia. Eur. J. Immunol. 24, 1167-1171.

45) Mathison, J.C., Tobias, P.S., Wolfson, E., Ulevitch, R.J. (1992): Plasma lipopolysaccharide binding protein. A key component in macrophage recognition of gram-negative LPS. J. Immunol. 149, 200-206.

46) Matsuura, M., Galanos, C. (1990): Induction of hypersensitivity to endotoxin and tumor necrosis factor by sub-lethal infection with Salmonella typhimurium. Infect. Immun. 58, 935-937.

47) Matsuura, M., Kiso, M., Hasegawa, A., Nakano, M. (1994): Multistep regulation mechanisms for tolerance induction to lipopolysaccharide lethality in the tumor-necrosis-factor- $\alpha$-mediated pathway: Application of non-toxic monosaccharide lipid A analogues for elucidation of mechanisms. Eur. J. Biochem. 221, 335-341. 
48) McGeehan, G.M., Becherer, J.D., Bast Jr., R.C., Boyer, C.M., Champion, B., Connolly, K.M., Conway, J.G., Furdon, P., Karp, S., Kidao, S., McElroy, A.B., Nichols, J., Pryzwansky, K.M., Schoenen, F., Sekut, L., Truesdale, A., Verghese, M., Warner, J., Ways, J.P. (1994): Regulation of tumor necrosis factor- $\alpha$ processing by a metalloproteinase inhibitor. Nature 370, 558-561.

49) Milton, A.S., Wendlandt, S. (1971): Effect of body temperature of prosta-grandins of the $\mathrm{A}, \mathrm{E}$ and $\mathrm{F}$ series on injection into the third ventricle of unanesthetized cats and rabbits. J. Physiol. 218: 325-336.

50) Mohler, K.M., Sleath, P.R., Fitzner, J.N., Cerretti, D.P., Alderson, M., Kerwar, S.S., Torrance, D.S., Otten-Evans, C., Greenstreet, T., Weerawarna, K., Kronheim, S.R., Petersen, M., Gerhart, M., Kozlosky, C.J., March, C.J., Black, R.A. (1994): Protection against a lethal dose of endotoxin by an inhibitor of tumor necrosis factor processing. Nature 370, 218-220.

51) Morimoto, A., Murakami, N., Nakamori, T., Watanabe, T. (1988): Multiple control of fever production in the central nervous system of rabbits. J. Physiol. 397: 269-280.

52) Morimoto, A., Murakami, N., Takada, M., Teshirogi, S., Watanabe, T. (1987): Fever and acute phase response induced in rabbits by human recombinant interferon- $\gamma$. J. Physiol. 391: 209-218.

53) Murphy, P.A., Simon, P.L., Willoughly, W.F. (1980): Endogenous pyrogen made by rabbit peritoneal exsudate cells are identical with lymphocyte-activating factor made by rabbit alveolar macrophages. J. Immunol. 124: 2498-2501.

54) Nachman, R.L., Hajjar, K.A., Silverstein, R.Y., Dinarello, C.A. (1986): Interleukin 1 induces endotherial cell synthesis of plasminogen activator inhibitor. J. Exp. Med. 163, 1595-1600.

55) Nakamori, T., Morimoto, A., Yamaguchi, K., Watanabe, T., Murakami, N. (1994): Interleukin$1 \beta$ production in the rabbit brain during endotoxininduced fever. J. Physiol. 476: 177-185.

56) Neta, R., Oppenheim, J.J., Shreiber, R.D., Chzzonite, R., Ledney, G.D., MacVittie, T.J. (1991): Role of cytokines (interleukin 1, tumor necrosis factor, and transforming growth factor $\beta$ ) in natural and lipopolysaccharide-enhanced radioresistance. J. Exp. Med. 173, 1177-1182.

57) Ohlsson, K., Bjork, P., Bergenfeldt, M., Hageman,
R., Thompson, R.C. (1990): Interleukin-1 receptor antagonist reduces mortality from endotoxin shock. Nature 346, 550-552.

58) Okusawa, S., Gelfand. J.A., Ikejima, T., Connololy, R.J., Dinarello, C.A. (1988): Interleukin-1 induces shock-like state in rabbits: Synergism with tumor necrosis factor and effcet of cyclooxygenase inhibitor. J. Clin. Invest. 81, 1162-1172.

59) Parant, M. (1990): Possible mechanisms in endotoxin-induced modulation of non-specific immunity. 395-402, In Nowotny, A., Spitzer, J.J., Ziegler, E.J. [ed.], Cellular and molecular aspects of endotoxin reaction, Elsevier Science.

60) Parant, M., Galelli, A., Parant, F., Chedid, L. (1976): Role of B-lymphocytes in nonspecific resistance to Klebsiella pneumoniae infection of endotoxin-treated mice. J. Infect. Dis. 134, 531-539.

61) Pfeffer, K., Matsuyama, T., Kunding, T.M., Wakeham, A., Kishihara, K., Shahinian, A., Weigmann, K., Ohashi, P.S., Kronke, M., Mak, T.W. (1993): Mice deficient for the 55Kd tumor necrosis factor receptor are resistant to endotoxin shock, yet succumb to $L$. monocytogenes infection. Cell 73, 457-467.

62) Preiser, J.-C., Schmartz, D., Van der Linden, P., Content, J., Vanden Bussche, P., Buurman, W., Sebald, W., Dupont, E., Pinsky, M.R., Vincent, J.L. (1991): Interleukin-6 administration has no acute hemodynamic or hematologic effect in the dog. Cytokines 3, 1-4.

63) Rook, G.A.W., Taverne, J., Playfair, J.H.L. (1991): Evaluation of TNF as antiviral antibacterial and antiparasitic agent. Biotherapy 3, 167-175.

64) Rothe, J., Lesslauer, W., Lotscher, H., Lang, Y., Koebel, P., Kontagen, F., Althage, A., Zinkernagel, R., Steinmetz, M., Bluethmann, H. (1993): Mice lacking the tumor necrosis factor receptor 1 are resistant to TNF-mediated toxicity but highly susceptible to infection by Listeria monocytogenes. Nature 364, 798-802.

65) Rothstein, J., Schreiber, H. (1988): Synergy between tumor necrosis factor and bacterial products causes hemorrhagic necrosis and lethal shock in normal mice. Proc. Natl. Acad. Sci. USA 85, 607-611.

66) Schindler, R., Mancilla, J., Endres, S., Ghosbani, R., Clark, S.C., Dinarello, C.A. (1990): Correlations and interactions in the production of interleukin-6 (IL-6), IL-1, and tumor necrosis factor (TNF) in human blood mononuclear cells: IL-6 sup- 
presses IL-1 and TNF. Blood 76, 40-47.

67) Schumann, R.R., Leong, S.R., Flaggs, G.W., Gray, P.W., Wright, S.D., Mathison, J.C., Tobias, P.S., Ulevitch, R.J. (1990): Structure and function of lipopoly-saccharide binding protein. Science $\mathbf{2 4 9}$, 1429-1431.

68) Shinomiya, H., Hirata, H., Nakano, M. (1991): Purification and characterization of the $65 \mathrm{kDa}$ protein phosphorylated in murine macrophages by stimulation with bacterial lipopolysaccharide. J. Immunol. 146, 3617-3625.

69) Silva, A.T., Cohe, J. (1992): Role of interferon- $\gamma$ in experimental Gram-negative sepsis. J. Infect. Dis. 166, 331-335.

70) Starnes Jr., H.F., Pearce, M.K., Tewari, A., Yim, J.H., Zou, J.C., Abrams, J.S. (1990): Anti-IL-6 monoclonal antibodies protect against lethal Escherichia coli infection and lethal tumor necrosis factor- $\alpha$ challenge in mice. J. Immunol. 145, 4185-4191.

71) Stefanova, I., Corcoran, M.L., Horak, E.M., Wahl, L.M., Bolen, J.B., Horak, I.D. (1993): Lipopolysaccharide induces activation of CD14-associated protein tyrosine kinase p53/56 $6^{\mathrm{lyn}}$. J. Biol. Chem. 268, 20725-20728.

72) Tobias, P.S., Soldau, K., Ulevitch, R.J. (1986): Isolation of a lipopoly-saccharide-binding acute phase reactant from rabbit serum. J. Exp. Med. 146, 777-793.

73) Tobias, P.S., Soldau, K., Ulevitch, R.J. (1989): Identification of a lipid A binding site in the acute phase reactant lipopolysaccharide binding protein. J. Biol. Chem. 264, 10867-10871.

74) Tracey, K., Beutler, B., Lowry, S.F., Merryweather, J., Wolpe, S., Milsark, I.W., Hariri, R.J., Fahey, T.J., Zentella, A., Albert, D., Shires, G.T., Cerami, A. (1986): Shock and tissue injury induced by recombinant human cachectin. Science 234, 470-474.

75) Tracey, K.J., Fong, Y., Hess, D.G., Manogue, K.R., Lee, A.T., Kou, G.C., Lowry, S.F., Cerami, A. (1987): Anti-chachectin/TNF monoclonal antibodies prevent septic shock during lethal bacteremia. Nature 330, 662-664.

76) Tzung, S.-P., Mahl, T.C., Lance, P., Andersen, V., Cohen, S.A. (1992): Interferon- $\alpha$ prevents endotoxin-induced mortality in mice. Eur. J. Immunol. 22, 3097-3101.

77) Van der Meer, J.W.M., Barza, M., Wolff, S.M., Dinarello, C.A. (1988): Low dose recombinant in- terleukin-1 protects glanulocytopenic mice from gram-negative infection. Proc. Natl. Acad. Sci, USA 85, 1620-1623.

78) Van der Poll, T., Levi, M., Hack, C.F., Ten Cate, H., Van Deventer, S.J.H., Eerenberg, A.J.M., De Groot, E.R., Jansen, J., Gallati, H., Buller, H.R., Ten Cate, J.W., Aaranden, L.A. (1994): Elimination of interleukin 6 attenuates coagulation activation in experimental endotoxemia in chimpanzees. J. Exp. Med. 179, 1253-1259.

79) Van Zee, K.E., Kohno, T., Fisher, E., Rock, C.S., Moldawer, L.L., Lowry, S.F. (1992): Tumor necrosis factor soluble receptors circulate during experimental and clinical inflammation and can protect against excessive tumor necrosis factor $\alpha$ in vitro and in vivo. Proc. Natl. Acad. Sci. USA 89, 4845-4849.

80) Vlich, Th.R., Guo, K., Remick, D., Del Castillo, J., Yin, S. (1991): Endotoxin-induced cytokine gene expression in vivo. III. IL-6 mRNA and serum protein expression and the in vivo hematologic effects of IL-6. J. Immunol. 146, 2316-2323.

81) Vogel, S.N., Herincson, B.E. (1990): Role of cytokines as mediators of endotxin-induced manifestation: A comparaison of cytokines induced by doses of LPS and MPL that elicit comparable early endotxin tolerance. 465-474, In Nowotny, A., Spitzer, J.J., Ziegler, E.J. [ed.], Cellular and molecular aspects of endotoxin reaction, Elsevier Science.

82) Vogels, M.T.E., Henmsen, C.C., Huys, H.L.P.G., Eling, W.M.C., Van der Meer, J.W.M. (1994): Roles of tumor necrosis factor alpha, granulocytemacrophage colony-stimulating factor, platelet-activating factor, and arachidonic acid metabolites in interleukin-1-induced resistance to infection in neutropenic mice. Infect. Immun. 62, 2065-2070.

83) Vogels, M.T.E., Lindley, I.J.D., Curfs, J.H.A.J., Eling, W.M.C., Van der Meer, J.W.M. (1993): Effects of interleukin-8 on nonspecific resistance to infection in neutropenic and normal mice. Antimicrob. Agents Chemother. 37, 276-280.

84) Waage, A. (1987): Production and clearance of tumor necrosis factor in rats exposed to endotoxin and dexamethason. Clin. Immunol. Immunopathol. 45: 348-355.

85) Waage, A., Brandtzaeg, P., Halstensen, A., Kierulf. P., Espevik, T. (1989): The complex pattern of cytokines in serum from patients with meningococcal septic shock. Association between in- 
terleukin 6 , interleukin 1 , and fatal outcome. J. Exp. Med. 169, 333-338.

86) Waage, A., Espevik, T. (1988): Interleukin 1 potentiates the lethal effect of tumor necrosis factor $\alpha /$ cachectin in mice. J. Exp. Med. 167, 1987-1992.

87) Wakabayashi, G., Gelfand, J.A., Burke, J.F., Thompson, R.C., Dinarello, C.A. (1991): A specific receptor antagonist to interleukin-1 prevents Escherichia coli-induced shock in rabbits. FASEB J. 5, 338-343.

88) Wright, S.D., Ramos, R.A., Tobias, P.S., Ulevitch, R.J., Mathison, J.C. (1990): CD14, a receptor for complexes of lipopolysaccharide (LPS) and LPS binding protein. Science 249, 1431-1433.

89) Zampronio, A.R., Souza, G.E., Silva, C.A., Cunha, F.Q., Ferreira, S.H. (1994): Interleukin-8 induces fever by a prostagrandin-independent mechanism. Am. J. Physiol. 266, R1670-1674.

90) Zuckerman, S.H., Qureshi, N. (1992): In vivo inhibition of lipopoly-saccharide-induced lethality and tumor necrosis factor synthesis by Rhodo-bacter sphaeroides diphosphoryl lipid A is dependent on corticosteron induction. Infect. Immun. 60, 2581-2587. 